\title{
Assessment of Survival Edible Wild Plants and Relative Abundance in Ikwe Game Reserve, Nigeria
}

\author{
Abubakaar, E.M. ${ }^{1}$, Dau, J.H.* \\ ${ }^{I}$ Department of Forestry Technology, College of Agriculture, Yelwa, Bauchi, Bauchi State-Nigeria. \\ ${ }^{2}$ Department of Forest Production and Products, College of Forestry and Fisheries, University of Agriculture, \\ Makurdi-Nigeria.
}

*Corresponding Author: Dau, J.H., Department of Forest Production and Products, College of Forestry and Fisheries, University of Agriculture, Makurdi-Nigeria.

\begin{abstract}
Many of biodiversity species are under threat of extinction as pressure on them increases. A threat to these economic plant species means a threat to the survival of the rural people. This study was carried out in Ikwe game reserve Benue, Nigeria with an aim to assess the survival edible wild plants. A transect line of $1 \mathrm{~km}$ was laid at an interval of 100 meters along each transect. A sample plot sizes $25 \times 25$ meters were randomly laid at 20 meters apart at both side of the transects. Complete enumeration of edible wild plants species were identified and recorded within each sample plot in the study area. The result showed a total of twelve (12) economic species of edible wild plants were surviving in the study area. The most dominant species (Isoberlina doka) present within the reserve was not an edible plant. The study area faces anthropogenic activities, thereby affecting the abundance of edible species in the study area. The most edible plants were Parkia biglobosa and Prosopis Africana. These species have high economic value to the Community. The presence of edible plant species like Vitex doniana was relatively high in abundance; this could be due to the fact that it was scarcely utilized by the local people or because of their limited ideas about its nutritional contents. The non relative abundance of edible wild plants in the study area had an implication that could be attributed to high rate of degradation of the reserve; which had become bare ground due to anthropogenic activities. The Reserve is an asset that the Government or any Non Governmental Organization can explore for its renewable potentials and richness, scenery and other natural features. It has the potentials of becoming a major source of revamping the local economy of the rural people. It is recommended that the local communities should be empowered economically, so they can have alternative sources of livelihood that are biodiversity friendly, thus reducing their dependence on the reserve.
\end{abstract}

Keywords: abundance, biodiversity, conservation, edible plants, economic value.

\section{INTRODUCTION}

Millions of people in many developing countries do not have enough food to meet their daily requirements and furthermore people are deficient in one or more macro and micro nutrients [1]. Rural communities in most cases depend on wild resources including wild edible plants to meet their food needs in periods of food crisis [2]. The existence of plants species in any habitat is crucial to man and other components of the ecosystem as all plants are valuable for one purpose or the other [3].

There are close to 8,500 units of protected areas throughout the world, distributed across the various continents [4]. According to Marguba [5], there are some 30,000 protected areas around the world and it is touted as one of the greatest achievements of the $20^{\text {th }}$ century and a great inheritance for $21^{\text {st }}$ century. Over the last two decades, there has been a relatively rapid growth in game reserve and, or protected areas obviously due to the perceived importance attached to them [5].

Indiscriminate fuel wood gathering, timber harvesting and overgrazing have aggravated land degradation process in many parts of the tropics [6]. Nigeria's natural forest resources are fast diminishing and they may be exhausted by the end of the century as many species of flora and fauna are threatened [7]. As soon as the vegetative cover of the soil is removed, the protective influence of the forest is reduced to the barest minimum. Soil conservation and improvement of the forest values are immediately lost and erosion sets in. Agbelusi [8], in a paper tagged "conservation of biodiversity" asserted that Nigeria like many African countries is faced with the problems of 
environmental destruction fueled by increase in population growth, political instability and increasing poverty.

Species are lost and biodiversity is obtainable only in the National Park, Game reserve, Forest reserves, Wildlife sanctuary. About 36 countries all over the world now face food [9]. Forest foods can offer vital insurance against malnutrition or famine during times of seasonal food shortage. It is common for low income earners to depend on forest foods. Women, in particular, depend on these resources for supplementary nutrition, emergency foods, fuel wood and charcoal for cooking, medicine, income and many other important products they need to ensure the nutritional well-being of their families [10;11] Conservation Africa Foundation (CAF), [11].

Afolayan and agbelus [12] asserted that vegetation makes up the habitat of wildlife species and it's absence will imply the extinction of wild animals since it provide food, cover and escape cover for the wildlife species. Wild plants constitute the main medicinal resources in many traditional societies. The problem of food insecurity looms large in developing countries as incidence of poverty is on the increase and defies any precise solution [13]. Millions of the world's most vulnerable - the rural poor, are facing starvation as food shortage bites hard and prices of food crops move upward every day [9].

Many of biodiversity species are under threat of extinction as pressure on them increases. A threat to these plant species means a threat to the survival of the rural poor and low income earners. There is the need to survey the edible wild plants within the reserve area. This finding would provide the basic data for an effective management of wildlife species. Also, it would provide baseline information for an effective ecological management of the Ikwe Game Reserve; this will also assist the present and future planning of the Ikwe Game Reserve.

\section{Materials AND Methods}

\subsection{Study Area}

The study was carried out at Ikwe game reserve. Ikwe Game Reserve is located in Igbor, Gwer Local Government Area of Benue state, Nigeria. It lies about thirty kilometers $(30 \mathrm{~km})$ north of Makurdi, the state capital. The towns and villages bordering the reserve are: Otukpo and Aliade (South), Igbor (West), Kwagh Akume and Koodar (East) and Makurdi (North). The reserve lies between latitude 7 $30^{\prime} \mathrm{N}$ and longitude $88^{\circ} \mathrm{E}$. It is surrounded by Ikwe hills and its size a total area of about $40 \mathrm{~km}^{2}$. The distinctive climate of the game reserve is wet and dry season which vary from year to year. The dry season occurs between November to March and the wet season occurs between Aprils to October. The reserve lies in the southern Guinea savanna. The annual rainfall ranges from $1,140 \mathrm{~mm}$ to $1,520 \mathrm{~mm}$ and evapo-transpiration is between $0.40-0.70$. The average temperature is about $30^{\circ} \mathrm{c}$ and relative humidity between $60 \%$ and $80 \%$ [14]. The vegetation of area is characterized by the growth of shoots, grasses, thorns, reaching the height of 1.3 to 1.5 meters. The vegetation consists of open woodland with short bole and broad leaf. The trees are about $12 \mathrm{~m}-15 \mathrm{~m}$ high and rarely up to $27 \mathrm{~m}$ or over $30 \mathrm{~m}$. The major ethnic group is Tiv, with farming as the major.

\subsection{Data Collection and Analysis}

Edible wild plants in the reserve were assessed and data were collected. A transect line of $1 \mathrm{~km}$ was laid at an interval of 100 meters along each transect. A sample plot sizes $25 \times 25$ meters were randomly laid at 20 meters apart at both side of the transects. Complete enumeration of edible wild plants species were identified and recorded within each sample plot in the study area. All edible plants were identified and checklists compiled [17; 18]. Descriptive statistics analysis of variance (ANOVA) were used to analyze the data and to test for significant differences at $\mathrm{P}<0.05$ levels of significance.

\section{RESULTS AND DiSCUSSION}

The result on Table 1 showed a total of twelve (12) different economic species of edible wild plants assessed from the study area. These species include Prosopis africana, Vittelaria paradoxa, Parkia biglobosa, Emilia coccinea, Afzelia africana, Bombax costatum, Cissus populnea, Vitex doniana e.t.c. The most dominant specie present within the reserve which was not an edible woody plant is Isoberlina doka. The few numbers of edible species in the reserve area faces the problem of regular felling of trees, poaching of fauna resources, cattle trampling and farming activities. 
Table1. Some Economic Edible Wild Plants in Ikwe Game Reserve

\begin{tabular}{|l|l|l|l|}
\hline S. No. & \multicolumn{1}{|c|}{ Family Name } & \multicolumn{1}{|c|}{ Scientific Name } & \multicolumn{1}{|c|}{ Local name } \\
\hline 1 & Caesalpinioideae & Afzelia Africana & Yiase \\
\hline 2 & Bombacaceae & Bombax costatum & Ginger \\
\hline 3 & Vitaceae & Cissus populnea & Ager \\
\hline 4 & Palmae & Elaeis guineensis & Ikye or Ivile \\
\hline 5 & Abteraceae & Emilia coccinea & Aninge \\
\hline 6 & Mimosoideae & Parkia biglobosa & Nune \\
\hline 7 & Mimosoideae & Prosopis Africana & Gbaaye \\
\hline 8 & Apocynaceae & Saba comrensis & Apungwa \\
\hline 9 & Loganiaceae & Strychnos spinosa & Maku \\
\hline 10 & - & Tacca leontopetaloides & Gbache \\
\hline 11 & Verbenaceae & Vitex doniana & Hulugh \\
\hline 12 & Sapotaceae & Vittelaria Paradoxa & Chamegh \\
\hline
\end{tabular}

This finding showed that a total of twelve (12) edible wild plants were identified (Table 1). The fewer numbers of edible wild plants in the study area could be attributed to the rate of logging, human encroachment and exploitation of the edible flora resources without any sustainable management of the reserve. This result implies that the edible wild plant species in the study area were threatened and poorly abundance due to poor conservation and management of the game reserve by the Government and the surrounding communities. The present conservation status of this game reserve contradicted the report of Marguba [5], which reported that there has been a relatively rapid growth in game reserve and, or protected areas obviously due to the perceived importance attached to them.

Krishna [4], reported that there are different types of protected areas and the purpose for their establishment also varies; it is to maintain the life supporting diversity of ecosystems. But the result from this finding showed that the reserve does not maintain the life supporting diversity of the study area due to poor abundance of economic and edible wild plants species. This could be as a result of poverty and low agricultural output experienced within the country over the past two years. Also, it could be due to the increasing recognition of their importance to community needs for improved rural livelihood; household food security and nutrition; employment generation and income supplements. Forests contribute in many ways to combating malnutrition and improving diets in local communities and rural households $[13 ; 2 ; 10]$.

The composition of these edible plants species in terms of relative abundance were the same in the sampled vegetation (the River area, upland (hill) and the Open area). This finding agreed with Ogundele et al. [17], which reported that, the relative scarcity of most of the NTFPs as a result of deforestation. The most edible wild plants were Parkia biglobosa and Prosopis africana. This agrees with the works of Mohammed ET $a$. [18], which reported that the most widely used edible wild plants in Nigeria were Parkia biglobosa and Prosopis africana.

Table 2, presented the result on the utilization of edible wild plant's part in the study area. The most widely utilized edible wild plants in the study area were Parkia biglobosa and Prosopis africana with their local names as gbaaye and nune, respectively, by the Tiv people in Benue state. Other edible wild plants surveyed include Afzelia africana, Bombax costatum, Elaeis guineensis, Emilia coccinea and Tacca leontopetaloides among others. The edible wild plants were mostly utilized by parts used such as seeds, calyx, roots, stems, fruits or tubers depending on the tree plant species and it uses. These plant species were mostly utilized as soup condiment (Afzelia Africana, Parkia biglobosa and Prosopis africana), soup (Cissus populnea), oil (Elaeis guineensis and Vittelaria Paradoxa), and vegetable (Vitex doniana) implement and crafting materials (Prosopis africana). Other edible plant's part is utilized by seeds, fruits, leaves and root/tubers.

Table2. Utilization of Economic Edible Plants Parts in Ikwe Game Reserve

\begin{tabular}{|l|l|l|l|l|}
\hline S/N & \multicolumn{1}{|c|}{ Scientific Name } & \multicolumn{1}{|c|}{ Parts used } & \multicolumn{1}{|c|}{ How it is use } & \multicolumn{1}{c|}{ Used } \\
\hline $\mathbf{1}$ & Afzelia africana & Seeds & Processed & soup condiment \\
\hline $\mathbf{2}$ & Bombax costatum & Calyx & Fresh, dry, processed & soup \\
\hline $\mathbf{3}$ & Cissus populnea & stem/Leaves & Processed & Soup \\
\hline $\mathbf{4}$ & Elaeis guineensis & Fruits & Fresh, processed & Soup, oil \\
\hline $\mathbf{5}$ & Emilia coccinea & Leaves & Processed & Soup, vegetables \\
\hline
\end{tabular}




\begin{tabular}{|l|l|l|l|l|}
\hline $\mathbf{6}$ & Parkia biglobosa & Seeds, fruits & Processed & Soup, food \\
\hline $\mathbf{7}$ & Prosopis africana & Seeds, stem & Processed & Soup, condiment, implements \\
\hline $\mathbf{8}$ & Saba comrensis & Seeds & Processed & Food \\
\hline $\mathbf{9}$ & Strychnos spinosa & Fruits & Processed & Food \\
\hline $\mathbf{1 0}$ & Tacca leontopetaloides & Tuber & Processed & soup delicacy \\
\hline $\mathbf{1 1}$ & Vitex doniana & Fruits/leaves & Fresh & Vegetable \\
\hline $\mathbf{1 2}$ & Vittelaria Paradoxa & Fruits & Processed & Oil \\
\hline
\end{tabular}

The utilization of the plant parts vary in their importance and benefit to man; and can provide essential nutritional requirements, especially vitamins and micronutrients. These species of edible wild plant are said to have vital nutritional supplements especially their richness in vitamins and micronutrients they provides to the rural people and urban low income earners. This could be probably due to high value attached to the trees species and their economic importance to the rural community. They serve as local condiments to the local people. This finding is in accord with Olapade and Bakare [3], which reported that the existence of plants species in any habitat is crucial to man and other components of the ecosystem as all plants are valuable for one purpose or the other. Also, Balemie and Kebebew [2], reported that rural communities in most cases depend on wild resources including wild edible plants to meet their food needs in periods of food crisis.

This finding showed (Table 3) that vitex doniana and Tacca leontopetaloides had the highest percentage (17.7) relative abundance in Ikwe Game Reserve while the Emilia coccina has the least percentage (3.58) of relative abundance in Ikwe Game Reserves. Vitellaria paradoxa had $17.56 \%$ as the relative abundance in Ikwe Game Reserves. The result showed that the three areas in Ikwe Game Reserves, upland area was the most populated area with edible wild plants which had 118 total covered with wild plants species followed by River side area which had 108 while the least populated area was Open field area with 53.

Table3. Relative Abundance of Edible Wild Plants in the Study Area

\begin{tabular}{|l|l|l|l|l|l|}
\hline \multicolumn{1}{|c|}{ Scientific Name } & River side & upland area & Open field & Total $(\%)$ & Relative abundance \\
\hline Afzelia africana & 0 & 13 & 9 & 22 & 7.89 \\
\hline Bombax costatum & 19 & 9 & 1 & 11 & 3.94 \\
\hline Cissus populnea & 22 & 0 & 1 & 23 & 8.24 \\
\hline Elaeis guineensis & 3 & 0 & 0 & 3 & 1.08 \\
\hline Emilia coccinea & 7 & 0 & 3 & 10 & 3.58 \\
\hline Parkia biglobosa & 11 & 17 & 13 & 41 & 14.7 \\
\hline Prosopis africana & 20 & 13 & 5 & 38 & 13.63 \\
\hline Saba comrensis & 18 & 0 & 0 & 8 & 6.45 \\
\hline Strychnos spinosa & 3 & 7 & 14 & 24 & 8.60 \\
\hline Tacca leontopetaloides & 0 & 20 & 0 & 20 & 17.7 \\
\hline Vitex doniana & 6 & 14 & 0 & 20 & 17.7 \\
\hline Vittelaria Paradoxa & 17 & 25 & 7 & 49 & 17.56 \\
\hline Total & $\mathbf{1 0 8}$ & $\mathbf{1 1 8}$ & $\mathbf{5 3}$ & $\mathbf{2 7 9}$ & $\mathbf{1 0 0}$ \\
\hline
\end{tabular}

The presence of edible plant species (Vitex doniana) (Table 3) was relatively high in abundance could be due to the fact that it is scarcely utilized by the local people or because of their limited ideas about its nutritional contents. These species were the commonest species in the Guinea savanna zone of Nigeria [12]. The non relative abundance of edible wild plants in the study area (Table 3) had an implication that could be attributed to high rate of degradation of the reserve. This has become bare ground due to anthropogenic activities; such as indiscriminate exploitation of trees, farming activities, grazing and bush burning. Others activities including: farming, firewood processing and logging. This result is in accord with the findings of Afolayan and Agbelusi [19], which reported that man, interferes with reserve through clearing of vegetation for farming, firewood for fuel consumption and indiscriminate use of fire. Also, Ogundele et al. [17], reported that the relative scarcity of most of the NTFPs was as a result of deforestation. While Umeh [7], observed that Nigeria's natural forest resources are fast diminishing and that they may be exhausted by the end of the century as many species of flora and fauna are threatened.

\section{CONCLusion}

Based on this finding, Vitex doniana was relatively high in terms of abundance. There was no relative abundance of edible wild plants distributed in the study area. This could be due to anthropogenic 
activities carried out in the area. The most edible plant species mostly exploited for consumption within the area were P. africana and P. biglobosa. These plants species have high economic value to the people of the community in the study area; the plants are multipurpose species. Ikwe Game Reserve is an asset that the Government or any Non Governmental Organization can explore for its renewable potentials and richness in terms of flora and fauna resources, scenery and other natural features. It has the potentials of becoming a major source of revamping the local economy of the rural people and the state at large since the economy of most of the east African countries depends on tourism. If only the reserve will be given the needed attention. Therefore, it is recommended that: the local communities should be empowered economically, so that they can have alternative sources of livelihood that are biodiversity friendly, thus reducing their dependence on the reserve. Laws and edicts establishing the reserve should be revised so as to make amendments and incorporate measures that will serve as panacea to the present problems that are impeding the growth and success of game reserves in most developing countries.

\section{REFERENCES}

[1] Food and Agricultural Organisation. State of the World forest, Rome; 2004: 5-98.

[2] Balemie K. \& Kebebew F. Ethobotanical study of wild edible plants in Derashe and Kucha District, South Ethiopia. 2006; http://www.publiccentral.nih:gov/reirect3.gi.

[3] OlapadeO.E, \& Bakare O.A. Medicinal plants in Ibadan under threat of genetic erosion; Our Forest, Environment and Heritage; Challenges for Our People, Akinsanmi FA (ed). Proceedings of $22^{\text {nd }}$ Annual Conference of ForestrAssociation of Nigeria Held in Kano, Kano State, Nigeria; 1992: 55-58.

[4] Krishna, B.G. Social Changes and Conservation, Published by Earth scan publication limited UK; 1997.

[5] Marguba L.B., National Park and their Benefit to Local Communities in Nigeria; 2002

[6] Bene et al, 1997: The Nigeria Journal of Forestry published by Forestry Association of Nigeria vol. 34 (1 \& 2) 2004.Cavendish W. 2001. Non-timber Forest Products And Rural Poverty: An Economic Analysis. Evans J (ed) Forests HandbookVol. 1. An Overview of Forest Science. Blackwell Science Ltd; 372-390. FAO. 2000. Non-Wood News. An Information Bulletin of Non-wood Forest Products. 95pp.

[7] Umeh, The Nigeria Journal of Forestry published by Forestry Association of Nigeria 34 (1 \& 2) 2004.

[8] Agbelusi E.A., Conservation of Biodiversity. Paper presented at the year 2000 World Environmental day in Akure, Ondo State.

[9] Smith K. and Edward. The year of global food crisis. 2008. http://www.sundayherald.com/ news/display.var.2104849.0.2008-theyear of-global-food -crisis .php.

[10] Jimoh S.O. and Haruna E.A. Contribution of non-timber forest products to house food security and income around Onigambari forest reserve, Oyo State, Nigeria. Journalof Environmental Extension, 2007, 6: 28-33.

[11] Conservation Africa Foundation (CAF). 2008. Non-timber forest products: Breaking the vicious cycle of poverty and degradation in Africa. http://www.conserveafrica.org.uk/poverty.php

[12] Afolayan T.A. and Agbebusi E.A.; Impact of Seasonal Wildlife on biodiversity in Biennial Conference of ECOSON, University of Agriculture, Abeokuta Nov. $23^{\text {rd }}-27^{\text {th }} 1997$.

[13] Odebode S. Contribution of selected non-timber forest products to household food security in Osun State, Nigeria. 2005.

[14] Agricultural resources in Benue state Nigeria (ARB) 2007

[15] Joyce L. and Soladye, M.O. Flora of west Tropical African $2^{\text {nd }}$ Edition, Nigeria J Botany 3:1-24; 1990.

[16] 16. Hopkins, B. and Stanfield, D.P. A field key to savanna Trees of Nigeria, Ibadan University Press; 1966: 45.

[17] Afolayan.T.A and Agbelusi E.A.; an overview of the role of fire in the management of savanna ecosystem in the west African Sub-Region. In: Proceedingof the Regional Training Workshop held at FUTA Akure, Nigeria Between $23^{\text {rd }}-26^{\text {th }}$ July, 1995. p. 61-92.

Citation: E.M. Abubakaar, J.H. Dau, "Assessment of Survival Edible Wild Plants and Relative Abundance in Ikwe Game Reserve, Nigeria", International Journal of Forestry and Horticulture, vol. 4, no. 1, p. 19-23, 2018. http://dx.doi.org/10.20431/2454-9487.0401003

Copyright: () 2018 Authors. This is an open-access article distributed under the terms of the Creative Commons Attribution License, which permits unrestricted use, distribution, and reproduction in any medium, provided the original author and source are credited. 